\title{
Tokion innostuksesta Pariisin diplomaattiseen kyynisyyteen
}

\section{- huomioita kansainvälisen tilanteen vaikutuksesta Unescon aikuiskasvatuskonferensseihin}

\begin{abstract}
Savolainen, Kaisa. Tokion innostuksesta Pariisin diplomaattiseen kyynisyyteen - huomioita kansainvälisen tilanteen vaikutuksista Unescon aikuiskasvatuskonferensseihin. Aikuiskasvatus 5, 2, 56-60. - Kirjoittaja esittelee artikkelissaan Pariisissa keväällä 1985 pidetyssä Unescon 4. kansainvälisessä aikuiskasvatuskonferenssissa tehtyjä tärkeimpiä päätöksiä. Hän tarkastelee myös, miten kansainvälinen tilanne on näkynyt Unescon aikuiskasvatuskonferenssien osallistujien määrissä, käsiteltävien asioiden sisällöissä sekä konferenssin työskentelytavoissa. Lopuksi tarkastellaan konferenssien merkitystä ja tulevaisuutta.
\end{abstract}

\section{Oppimisen oikeus tunnustettiin}

"Oppimisen oikeuden tunnustaminen on nyt jos koskaan yksi ihmiskunnan suurimpia haasteita", alkaa neljännen, Unescon järjestämän kansainvälisen aikuiskasvatuskonferenssin yksimielisesti hyväksytty julistus, Oikeus oppia (Right to learn). Konferenssi pidettiin Pariisissa 19. - 29. maaliskuuta.

Äkkipäätään saattaisi ihmetellä, miksi konferenssi antaa itsestään selvältä tuntuvan julistuksen. Kuitenkaan julistuksen sisältö ei ole itsestäăn selvyys tämän päivän maailmassa.

Julistuksen mukaan oikeus oppia on:

- oikeus lukea ja kirjoittaa,

- oikeus kysellä ja analysoida,

- oikeus mielikuvitukseen ja luovuuteen,

- oikeus lukea omaa maailmaansa ja kirjoittaa historiaa,

- oikeus päästä osalliseksi koulutuksen palveluista,

— oikeus kehittää yksilöllisiä ja kollektiivisia kykyjä.

Lisäksi julistuksessa todetaan mm. "oppimisen oikeus on välttämätön väline ihmiskunnan säilymiselle, ravinnon tuotannolle ja muille välttämättömille inhimillisille tarpeille. Jos haluamme välttää sotaa, meidän on opittava elämään rauhassa ja opittava ymmärtämään toinen toisiamme. Oppiminen muuttaa ihmiset asioitten armoilla olevista kohteista subjekteiksi, jotka luovat oman historiansa."

Julistuksessa mainittu ensimmäinenkin oikeus, oikeus lukea ja kirjoittaa, puuttuu tänään vielä 889 miljoonalta ihmiseltä. Heistä $60 \%$ on tyttöjä ja naisia. Lukutaidottomista suurin osa, $98 \%$ asuu kehitysmaissa. Myös teollistuneissa maissa ongelma on olemassa lähinnä toiminnallisena lukutaidottomuutena. Vaikka nämä ihmiset pystyvätkin jotakin lukemaan ja kirjoittamaan, niin eivät kuitenkaan riittävästi selviytyäkseen yhteiskunnan vaatimuksista. Esim. USA:n konferenssin valmisteluja varten tekemän raportin mukaan on siellä arvioitu olevan 26 miljoonaa toiminnallisesti lukutaidotonta ja lisäksi $\mathbf{4 6}$ miljoonaa sellaista, joilla on niin puutteellinen lukutaito, etteivät he selviydy aikuisten suoritustasolle sitä mittaavassa testissä (adult performance level). Myös Espanjassa, Portugalissa ja Kreikassa on toiminnallisesti lukutaidottomien ongelma aikuiskasvattajien pulmana.

Miten syvällisesti julistuksen muut oikeudet on toteutettu tai tulisi toteuttaa yleensäkin koulutuksessa, on pohdinnan aihe, josta varmaa voidaan olla montaa mieltä. 


\section{Julistuksen taustasta}

"'Right to learn'" -julistuksen aikaansaamiseen liittyy konferenssia kuvaava mielenkiintoinen piirre. Julistus ei ollut alunperin minkään virallisen valtuuskunnan aloite, vaan tekstin saivat aikaan konferenssissa tarkkailijana olevien aikuiskasvatusjärjestöjen edustajat. Konferenssihan oli hallitustenvälinen. Näin ollen vain viralliset valtuuskunnat voivat tehdä esityksiä ja tarkkailijat voivat käyttää ainoastaan puheoikeutta. Tämän järjestöjen aikaansaaman julistuksen esitteli konferenssille virallisesti Kanadan edustaja monien muiden sitä tukiessa.

Järjestöt olivat siinä vaiheessa kokousta huolissaan sen yleisestä ilmapiiristä. Ei oltu varmoja, saisiko kokous aikaan yksimielisiä suosituksia. Julistuksella käsittääkseni haluttiin luoda aikuiskasvattajien keskinäistä yhtenäisyyttä, saada aikaan jotain sellaista, joka innostaisi ja jäisi mieleen nimenomaan Pariisin kokouksesta. Julistuksen haluttiin myös kielensä puolesta olevan jokaisen ymmärrettävissä ja eroavan tavanomaisista suositusteksteistä.

\section{Diplomaattien aikuiskasvatusta}

Tuossa vaiheessa konferenssia monet aikuiskasvatuksen asiantuntijat eri valtuuskunnissa olivat turhautuneita ulkoministeriöitten heidän mielestään liiallisesta puuttumisesta asioihin. Monessa läntisessä ja pohjoismaisessakin valtuuskunnassa kuohui pinnan alla juuri tästä syystä. Erään suuren länsimaan valtuuskunnan järjestöedustaja oli uhannut matkustaa kotiin ulkoministeriön edustajan halutessa ennakkoon tietää hänen puheensa. Aikuiskasvattajat eivät ole tottuneet kokouksissaan senlaatuiseen holhoukseen ja ulkoministeriöitten esiintymistä heidän mielestään substanssikysymyksissä arvosteltiin yksityisissä keskusteluissa.

Ulkoministeriöitten korostunut osuus erottikin Pariisin kokouksen vuonna 1972 Tokiossa pidetystä aikuiskasvatuskonferenssista, jolloin ulkoministeriön edustajat eivät aktiivisesti olleet mukana kokouksessa.

Onko aikuiskasvatus sitten politisoitunut tai muuttunut ulkopoliittiseksi runsaassa kymmenessä vuodessa? Käsittääkseni ei yhtään enempää tai vähempää kuin mitä se oli Tokion konferenssin aikoihin.

Sensijaan kansainvälinen tilanne on muuttunut. Erityisesti Unesco, mutta voidaan sanoa kansainvälinen monenkeskineri yhteistyö on nyt eräänlaisessa kriisissä. Varsinkin UंSAn Unescosta eron jälkeen on järjestöä voimallisestikin arvosteltu osassa länsimaista lehdistöä. Tämä tilanne on tuonut korostetusti esille ulkoministeriöitten osuuden nykyisin kaikissa Unescon kokouksissa. Ristiriitaa voi syntyä, koska aina ei voida selvästi vetää rajaa, mikä asia olisi pelkästään asiantuntijoiden päätettävä ns. substanssikysymys ja millä toisaalta arvioidaan olevan ulkopoliittisia vaikutuksia. On esitetty myös käsityksiä, että kun diplomaatit puuttuvat yhä enemmän kasvatuksen, tieteen ja kulttuurin kysymyksiin Unescossa, joudutaan noidankehään, missä järjestön alkuperäinen ajatus asiantuntijoiden ja tiedeihmisten yhteistyöstä entisestään hämärtyy ja järjestön tilanne vain pahenee.

\section{Aikuiskasvatus vakiinnuttanut asemansa}

Osanottajamäärien kehitys Unescon ensimmäisestä kansainvälisestä aikuiskasvatuskonferenssista neljänteen kuvaa toisaalta aikuiskasvatuksen merkityksen kehitystä ja aseman vakiintumista jäsenmaissa, toisaalta kansainvälisen yhteistyön kehitystä. Merkittävää on, että Pariisin konferenssin osanottajien määrä verrattuna Tokion konferenssiin on yli kaksinkertaistunut. Tämä siitä huolimatta, että kansainvälisen yhteistyön väitetään olevan kriisissä.

Kansainvälisiin aikuiskasvatuskonferensseihin osallistuminen

\begin{tabular}{|c|c|c|c|c|}
\hline \multicolumn{2}{|c|}{ Paikka } & \multirow{2}{*}{$\begin{array}{c}\text { Osan- } \\
\text { ottajat } \\
106\end{array}$} & \multirow{2}{*}{$\begin{array}{c}\text { Jäsen- } \\
\text { valtiot } \\
25\end{array}$} & \multirow{2}{*}{$\begin{array}{r}\text { Järjestöt } \\
21\end{array}$} \\
\hline I & $\begin{array}{l}\text { Elsinore } \\
\text { (1949) }\end{array}$ & & & \\
\hline II & $\begin{array}{l}\text { Montreal } \\
(1960)\end{array}$ & 177 & 47 & 46 \\
\hline & $\begin{array}{l}\text { Tokio } \\
(1972)\end{array}$ & 364 & 82 & 37 \\
\hline IV & Pariisi & 841 & 122 & 59 \\
\hline
\end{tabular}

(1985)

Nykyisin aikuiskasvatuksen merkitys on monissa maissa tunnustettu virallisesti $\mathrm{mm}$. lainsäädännössä. Merkittävää edistystä on tapahtunut lukutaitotyössä, käsitteet ovat vakiintuneet ja aikuiskasvatuksen tavoitteita, menetelmiä, rakenteita sekä muotoja on kehitetty huomattavasti. Aikuiskasvatus on integroitu yhä enemmän kansalliseen koulutusjärjestelmään. Aikuiskasvatuksen voidaan sanoa vakiinnuttaneen asemansa. 
Näin ei ollut vielä Unescon aikaisempien aikuiskasvatuskonferenssien aikaan, joista ensimmäinen pidettiin Elsinoressa 1949, neljä vuotta Unescon peruskirjan allekirjoittamisen jälkeen, toinen Montrealissa 11 vuotta myöhemmin 1960 ja kolmas Tokiossa 1982. Näitten kokousten osanottajat ja asiat heijastelivat luonnollisesti silloista kansainvälistä tilannetta ja aikuiskasvatuksen asemaa yhteiskunnissa.

Elsinoren konferenssissa, joka pidettiin toisen maailmansodan jälkitunnelmissa, edusti $70 \%$ osanottajista vielä 14 Länsi-Euroopan maata. Neuvostoliitto enempää kuin muutkaan sosialistiset maat eivät olleet mukana. Aasiasta, latinalaisesta Amerikasta, Afrikasta ja arabimaista oli yhteensä vain muutamia osanottajia. Silloin ei vielä yritettykään antaa aikuiskasvatukselle yhtenäistä määritelmää, vaan aikuiskasvatuksen tehtävänä nähtiin kunkin ryhmän erityistarpeet. Mielenkiintoista oli, että kampanjan lukutaidottomuutta vastaan katsottiin tuolloin olevan "teoreettisesti osa aikuiskasvatusta", mutta kuuluvan lähinnä peruskoulutukseen. Aikuiskasvatuksen roolia suvaitsevaisuuden ja yhteisymmärryksen lisääjänä korostettiin jo tuolloin.

Montrealin kokouksessa 1960 oli osanottajien joukossa jo Neuvostoliiton lisäksi viisi muuta sosialistista maata. Kokous heijasteli 1950-luvun poliittista ja yhteiskunnallista kehitystä. Teollistuminen ja kaupungistuminen toivat aikuiskasvatukselle uusia haasteita. Lukutaidon korostaminen nousi tärkeäksi asiaksi myös aikuiskasvatuksessa.

Tokion konferenssissa 1972 oli kehitysmailla jo enemmistö konferenssissa. Aasiasta oli 15, Afrikasta 19, arabimaista 10 ja latinalaisesta Amerikasta ja Karibian alueelta 17 valtuuskuntaa. Tokiossa mukana oli enemmän aikuiskoulutuspoliitiikan päättäjiä ja vanhempia virkamiehiä kuin aikaisemmissa kokouksissa.

Näin ollen Tokiossa keskityttiinkin enemmän koulutuspolitiikkaan, suunnitteluun, hallintoon ja talouteen kuin aikuiskasvatuksen teoreettisiin tai käsitteellisiin puoliin. Kaupungistuminen, teollistuminen, ympäristön ongelmat ja entisten siirtomaiden talous- ja koulutusongelmat näkyivät luonnollisesti kokouksessa. Tokion konferenssissa käsiteltiin ensimmäistä kertaa aikuiskasvatuksen roolia koulutuksen demokratisoijana ja yhteiskunnallisen ja kulttuurikehityksen tekijänä. Aikuiskasvatuksen merkityksen tunnustaminen ja elinikäisen koulutuksen käsitteen vakiintuminen todettiin tapahtuneen Montrealin kokouksen jälkeen.
Tokion konferenssin aikaan aikuiskasvatus oli meillä, kuten monissa muissakin maissa vasta tulossa suuremmassa määrin valtiollisen kiinnostuksen ja suunnittelun kohteeksi. Siinä mielessä Tokion konferenssilla saattoi olla merkittävämpikin osuus aikuiskasvatuksen kehittämiselle kuin mitä konferenssi voi tällä hetkellä tarjota. Tokiossahan päätettiin mm. siitä, että Unesco ryhtyy valmistelemaan kansainvälistä suositusta aikuiskasvatuksesta. Tämä suositus hyväksyttiin sitten Unescon yleiskokouksessa 1976. Suositus on vaikuttanut eri maiden kansallisiin aikuiskasvatuksen suunnitelmiin, joita on laadittu 1970-luvun lopussa ja 1980-luvulla.

Pariisin neljännessä aikuiskasvatuskonferenssissa osanottajat eri valtuuskunnissa edustivat voittopuolisesti virkamiehiä, mukaanlukien ulkoasiainministeriöitten edustajien korostunut osuus. Järjestöjen edustajia oli mukana valtuuskunnissa, mutta heidän vaikutuksensa oli taustalla, kuten tapahtui konferenssin julistuksen aikaansaamisessa. Mielenkiintoinen piirre oli myös pohjoismaisissa valtuuskunnissa järjestöjen vähäinen vaikutus, vaikka perinteisesti järjestöjen rooli aikuiskasvatuksessa on juuri pohjoismaissa ollut merkittävä. Sen voi arvioida vaikuttaneen huomattavasti koko Unescon aikuiskasvatustoimintaan, sillä pidettiinhän ensimmäinen kansainvälinen aikuiskasvatuskonferenssi Elsinoressa, Tanskassa.

\section{Erilaiset tunnelmat}

Tokion konferenssia vuonna 1972 leimasi aikuiskasvattajien innostuneisuus ja toiveikkuus. Toiveikkuus ulottui myös kansainvälisen yhteistyön mahdollisuuksien optimistiseen arviointiin. Nyt 1985 Pariisissa, kun kansainvälinen tilanne, ja erityisesti Unescon tilanne oli täysin toinen, latisti se myös kokouksen tunnelmia ja sisältöäkin.

Tokion konferenssin intensiivisyys johtui osaksi myös siitä, että kokous ei ollut Unescon päämajassa Pariisissa. Osanottajat olivat keskittyneet Tokiossa samoihin suuriin hotelleihin. Pariisissa kaikki hajaantuivat omille tahoilleen kokousistuntojen jälkeen. Ne Pariisissa tapaamani valtuuskunnan jäsenet, jotka olivat mukana myös Tokiossa muistelivat kaikki Tokion konferenssia parempana ja innostuneempana, erityisesti kokouksena, jossa kasvattajat määräsivät tahdin. 


\section{Pariisin konferenssi onnistui sittenkin}

Kaikesta huolimatta neljäs aikuiskasvatuskonferenssi Pariisissa kuitenkin lopulta onnistui. Konferenssi pääsi yksimielisyyteen suosituksista, jotka koskevat mm. aikuiskoulutuspolitiikkaa, eri ryhmien erityistarpeita, teknologiaa, aikuiskouluttajien koulutusta ja kansainvälistä yhteistyötä. Suositukset ovat varmasti hyödyllisiä ja mielenkiintoisia kaikille aikuiskasvatuksen parissa työskenteleville ja aikuiskasvatusta kehittäville. Yksimielisyyteen pääsy oli sitä merkittävämpää kun ottaa huomioon Unescon nykyisen tilanteen. Toisaalta se on myös osoitus siitä, että loppujen lopuksi halua ja tarvetta yhteistyöhön on. Kompromissit nähtiin tärkeämpänä kuin tilanteen kärjistäminen.

\section{Suositusten merkitys}

Kun valtuuskunnat tällaisissa jonkin alan kansainvälisissä konferensseissa esittävät suositusehdotuksia, sisällyttävät he niihin alan tärkeitä ja keskeisiä asioita. Toisaalta suositukset ovat kunnianhimoisia tavoitteita, toiveita siitä, miten asioiden pitäisi olla.

On syytä olettaa, että 4. aikuiskasvatuskonferenssin suositukset vaikuttavat Unescon omaan aikuiskasvatusohjelmaan viimeistään seuraavassa ohjelma- ja budjettiesityksessä. Mitkä suosituksista otetaan huomioon seuraavan ohjelman suunnittelussa, riippuu mm. jäsenmaitten kannanotoista Unescon yleiskokouksessa.

Jäsenmaille tarkoitettujen suositusten toteuttaminen taas riippuu kunkin jäsenmaan todellisesta halusta noudattaa niitä. Suositukset antavat esim. aikuiskoulutuksen kehittäjille ja järjestöille hyviä perusteita ja tukea. Suosituksilla on hallitustenvälisen konferenssin arvovalta ja jäsenvaltiot ovat niihin sitoutuneet, kun ovat olleet niitä kannattamassa ja hyväksymässä.

Tuleeko elinikäinen kasvatus kaikkien todellisuudeksi, saavutetaanko toiminnallinen lukutaito ja missä määrin aikuiskasvatuksella on merkitystä nykyajan suurten ongelmien ratkaisussa sekä maailman rauhan edistämisessä, riippuu jäsenvaltioitten kansallisesta koulutuspolitiikasta. Mutta on selvää, että ilman kansainvälistä yhteistyötä mm. noihin tavoitteisiin ei maailmanlaajuisesti tulla pääsemään.

\section{Valmistelujen merkitys}

Kansainvälisten konferenssien arvo ei ole pelkästään lopputuloksessa, vaan myös konferenssin valmisteluissa. Kun konferenssien väli on yli 10 vuotta, on luonnollista tarkastella sillävälin tapahtunutta kehitystä.

Aikuiskasvatuksen nykytilan selvittämiseksi oli Unesco tehnyt laajan kyselyn jäsenmaissa vuonna 1982. Vastausten perusteella oli laadittu katsaus alan kehitykseen Tokion konferenssin (1972) jälkeen. Lisäksi oli valmisteltu asiakirja aikuiskasvatuksen suuntaviivoista.

Tällaisten kehityssuuntien analysointi antaa käsityksen aikuiskasvatuksen tilanteesta kokonaisuutena, auttaa ongelmien tiedostamisessa ja voi antaa virikkeitä omalle kehittämistoiminnalle. Eri maitten aikuiskasvatusta kuvaavat raportit antavat kiinnostuneille yksityiskohtaisia tietoja asioiden järjestelyistä muissa maissa. Monet maat valmistelevatkin omaa aikuiskasvatustaan kuvaavia raportteja, joita kokouksen aikana lähetetään muille valtuuskunnille. Myös meiltä valmisteltiin englanninkielinen katsaus aikuiskasvatuksen kehityksestä.

Alueen kansainvälisen yhteistyön kohteitten suositteleminen perustuu ongelmien yhteiseen analysointiin myös kansainvälisissä valmistelevissa kokouksissa. Suomesta on osallistuttu Tanskan, Saksan liittotasavallan ja Italian Unesco-toimikuntien järjestämiin valmisteleviin kokouksiin. Tällaiset kokoukset luovat pohjaa myös varsinaisessa kokouksessa tapahtuvalle yhteistyölle.

\section{Konferenssien tulevaisuus}

Tuleeko vielä viidettä kansainvälistä aikuiskasvatuskonferenssia ja milloin se pidetään?

Aikuiskasvattajien kanta on, että kansainvälisiä aikuiskasvatuskonferensseja tarvitaan. Mielenkiintoista ja Unescon tilannetta kuvaavaa oli se, että kokouksessa jouduttiin äänestämään siitä, järjestetäänkö konferensseja "'tarpeen mukaan" vai "nykyistä useammin". Jos pelkästään aikuiskasvattajat olisivat voineet asiasta päättää, voisi arvioida, että tulos olisi ollut "nykyistä useammin". Mutta johtuen Unescon tilanteesta ja taloudellisista seikoista, joiden vuoksi järjestön budjettia joudutaan karsimaan, tuloksena oli että kokouksia järjestetään "tarpeen mukaan".

Aikuiskasvatuksen tehtävä on nähty yleensä suuremman yhteiskunnallisen oikeudenmukaisuuden saavuttamisen ja sivistyksellisen tasaarvon välineenä, toisaalta taloudellisen ja yh- 
teiskunnallisen kehityksen tekijänä, joka parantaa työn tasoa ja nostaa tuotantoa.

Maailmanlaajuisesti aikuiskasvatusta on kehitettävä yhdistämällä molemmat tehtävät ja sisällyttämällä mukaan maailmanrauhan säilyttämisen näkökulma. Tämän toteuttaminen edellyttää lisääntyvää kansainvälistä yhteistyötä, jota ilman ei tulla toimeen edes ennen viidettä kansainvälistä aikuiskasvatuskonferenssia.

\section{Konferenssin asiakirjat:}

- The Development of Adult Education - Aspects and Trends (ED-85/CONF 210/3).
- Adult Education since the Third International Conference on Adult Education (Tokyo, 1972). Round-up of Replies to the Survey carried out by Unesco among National Commissions with a view to gathering information on the development of Adult Education. (ED-85/CONF. 210/4).

- Fourth International Conference on Adult Education (Paris, 19-29 March 1985). Final Report.

Näitä dokumentteja on saatavissa kuudella kielellä (arabian, englannin, kiinan, ranskan, venäjän ja espanjan kielellä) Unescon Pariisin toimistosta, osoite: The Section of Adult Education, Unesco, 7, place de Fontenoy, 75700 Paris, France. 